ヒト肝硬変症に括ける BrdU 標識率の二峰性について

\begin{tabular}{llrrll} 
清水 & 昭男 & 原田 & 昌與 & \multicolumn{2}{l}{ 多羅尾和郎 } \\
岡本 & 直幸 & 杉政 & 征夫 & 武宮 省治* \\
有村 & 明彦** & 井上 & 達 & 蟹沢 & 成好***
\end{tabular}

Bromodeoxyuridine(BrdU)を用いた S 期細胞の検 出法は, 近年ヒト癌を中心に各種組織の細胞動態の解 析などに応用されている1。.我々は，BrdU in vitro 標 識法によりとト各種肝疾患に打ける S 期細胞を観察 ᄂ, 肝癌合併肝硬変症 (HCC-LC)は肝癌非合併肝硬変 症 (LC) に比して標識率高値となる傾向があること, LC 症例は標識率高値および低値の 2 群に分かれる傾 向があることを指摘してきだ．今回，LCの症例数を 累積, 標識率の分布につき新たな知見を得たので報告 する。

方法：対象は当院消化器内科および外科を受診した LC 症例37例, HCC-LC 症例28例, 腹腔鏡 なたは肝切除 術施行時に tru-cut 針にて肝硬变部より組織を採取し

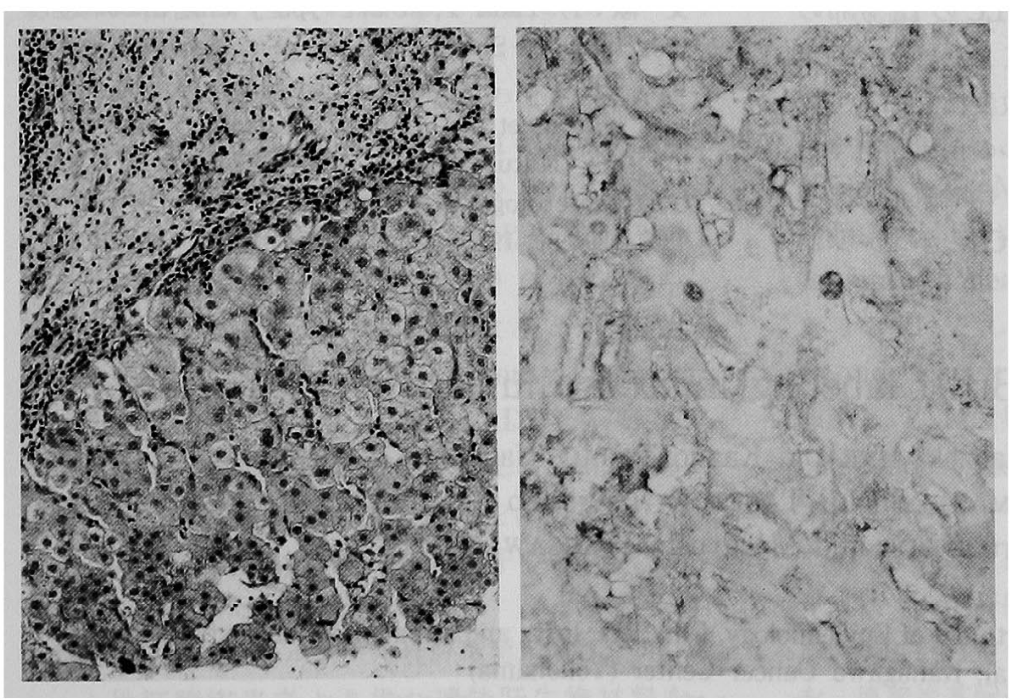

Fig. 1 A represetative microphotograph of a LC case. Left : H.E. stain, $\times 160$. Right : BrdU immunostain, $\times 320$.
た. 当該の標本で組織学的診断のつかなかったものも 含まれているが，癌部の組織採取が不可能であった HCC-LCについては画像診断により，またLCについ ては組織学的に癌を認めないことに加㐬像診断的に 占拠性病変を認めないことを根拠とした，採取された 材料を既報に従い (2,3), $0.1 \% \mathrm{BrdU}$ 溶液中, $37^{\circ} \mathrm{C} 45$ 分間 振盪培養後 $10 \%$ リン酸緩衝中性ホルマリンで固定, 型 のごとく $4 \mu \mathrm{m}$ のパラフィン切片を作成, 取り込まれた BrdU を免疫組織学的に検出し光顕的に観察した．各 摽本から無作為に抽出した5-7視野に含まれる肝細胞 合計1000個以上あたりの BrdU 陽性細胞核数を算定 し, 標識率 (LI) を千分率 $(\%)$ で求めた。結果の解 析は LIを自然対数変換した後に行い，解析後の数值 は指数変換によりもとの値に戻 して表示した。

成樍：代表的組織像を Fig. 1 飞示す. BrdU 陽性の核は単 独もしくは数個の小集団をなし て散在性に認められたが，偽小 葉周囲の線維成分との境界付近 に若干多く見られた．LCおよ びHCC-LC 各群の対数変換後 のLIの分布範囲をそれぞれ 10 等分して横軸に示し, 各階級の 症例数を綎軸にとったヒストグ ラムを Fig. 2 に示す. 図から明 らかなごと， LCは二つの頂 点を有しまた HCC-LCは一つ の頂点のみ有する分布となっ た. 平均 LIは LC11.2（標準偏 差の範囲 $3.9 \sim 32.8), \mathrm{HCC}$ -
・神奈川県立がんセンター臨床研究所病理，疫学， 同 病院消化器内科，外科

**横浜南共済病院内科

*** 横兵市立大学医学部病理学教室 〈受付日1989年 5 月 15 日 $>$
LC25.5（標準偏差の範囲16.0 40.9）であり，これら の平均値と標準偏差より導かれる正規分布から求めた 各階級の期待値と実測値との間に $\chi^{2}$ 検定を行らと, LCでは $\chi^{2}$ 值14.67 (自由度 9), HCC-LCでは $\chi^{2}$ 値 6.33(自由度 9) となり，LCがより対数正規分布から 

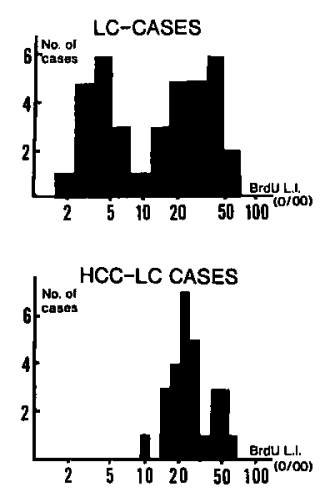

Fig. 2 Histogram of BrdU L.I. of LC cases and HCC-LC cases. Range of BrdU L.I. was devided into 10 classes after logarithmic transformation, and the number of the case included in each class was shown in the vertical axis.

離反していることが示唆された。なお両群の LI の平 均值にはWilcoxon の順位和検定により危険率 $5 \%$ \% 有意差を認めた。

考案：我々は，今回と同様の方法により各腫肝疾患 におけるS 期細胞を観察し，LI 高值の LC からは早期 に肝癌が発見される率が高いこと4)，LCの LI 分布の 標準偏差は大きいことなどを指摘してきた ${ }^{2,3)}$.今回新 たに累積された症例を加え, LI に対数変換を加えて解 析を行った結果, LC 症例の LIは2つの頂点を有する 分布を是し，一方，HCC-LC 症例の LI は対数正規分布 に従うことが示唆された。ささらに，LC症例のうち LI
高値群の LI は HCC-LC 症例の LI とほぼ同様の分布 を示すことがヒストグラムから推定された。肝細胞が 増殖する条件下では肝発癌が増加することは実験的に 証明されており 発癌しやすい状態にあることを示している可能性も考 えられる.しかしながら，LCから䀒癌の発生をみた 3 例についての肝癌発見に至るまでの観察期間は 9,18 , 24 月と短いこと4), 肝癌の発育は緩慢なるのが多い こと6), LI 高值の LC 症例と HCC-LC 症例の LI は忹 ぼ同様の分布を示すこと，などを考光合わせると，LC 症例の $5 ち \mathrm{LI}$ 高値のものは HCC-LC 之同様の理由に よる、すなわち、このような症例には診断不可能な程 度の小 HCC が既に発生している可能性も否定し難 い，LI高値をもたらす機構として，腫泻による増殖因 子の産生7や尰瘍による肝実質の損傷に対しての体液 性因子を介する反応"),などが考えられ，今後さらに検 討を要する，本法により，より早期に肝癌発生を発見 し得る可能性が示され，基礎的研究の手段としてのみ ならず，臨床的にも有用な情報をるたらす手法となり 得る可能性が示唆された。

索引用語：BrdU, 肝硬変症, 肝細胞癌

文 献：1) Tada $T$, et al: Jpn J Clin Oncol 16: 129, 1986 2) Shimizu A, et al : Hepatology 8: 1535,1988 3) 多羅尾和郎, 他：肝荿 $29: 488,1988$

4) Tarao $K$, et al: Cancer, in print. 5) Cayama E, et al : Nature $275: 60,1978$ 6) Okuda K, et al : Gastroenterology 73 : 109, 1977 7) 上木 㫒, 他： 肝葴 $29: 90,1988$ 8) 中村敏一：癌'86:111, 1986

\title{
Twin peak of the BrdU labeling index in human liver cirrhosis
}

\author{
Akio ShImizU, Masaoki HaRada, Kazuo TaRao, Naoyuki OKamoto, \\ Masao Sugimasa, Shouji TaKemiYA*, Akihiko ARIMURA**, \\ Tohru INOUE and Masayoshi KanISAWA***
}

\footnotetext{
* Department of Pathology, Department of Epidemiology, Clin. Res. Inst., and Department of Gastroenterology, Department of Surgery, Hospital, Kanagawa Cancer Center (Yokohama)

** Department of Internal Medicine, Yokohama Minami Kyousai Hospital (Yokohama)

*** Department of Pathology, Yokohama City University School of Medicine (Yokohama)
} 